\title{
二層屋根型円筒ラチスシェルの自由振動実験 \\ FREE VIBRATION TESTS OF DOUBLE-LAYER CYLINDRICAL LATTICED ROOFS
}

\author{
谷口 与史也*, 坂 壽 二** \\ Yoshiya TANIGUCHI and Toshitsugu SAKA
}

\begin{abstract}
Double-layer cylindrical latticed shells are widely used into a sports hall and convention hall, etc as a roof structure. The structural characteristics of them have been investigated theoretically and experimentally to grasp the buckling strength or dynamic behavior for seismic design. However, the free vibration behavior, in particular, the relation of damping ratios and frequencies has not been suffi'ciently investigated, yet. Then, in this paper, model experiments were carried out in order to make clear the free vibration behavior, that is, natural frequencies, damping ratios and the relations among them. It was consequently made clear that the damping ratios were inversely proportional to the natural frequencies for the latticed structures.
\end{abstract}

Keywords: damping ratio, natural frequency, model experiment, impulse method, double-layer latticed siructure 減衰定数, 固有振動数, 模型実験, 打撃試験, 二層立体ラチス構造

\section{1. はじめに}

学校体育館や公共スポーツ施設などの空間構造物は災害時の避難 場所として利用される場合が多く, その耐震性能の重要性は広く認 知されている。建築構造物の動的応答を検討する上で, 固有周期と 减衰定数峘重要な振動特性である。通常のラーメン構造による重層 建築物の固有振動数と減衰定数については, 数多くの実測および寒 験データがあり，明らかにされつつある1)。例えば鉄骨造建物の場 合, 1 次固有周期と軒高は明瞭な相関関係が得られている。1 次減衰 定数は概ね慣用值 $2 \%$ 以下の範囲に分布しているが高次減衰定数は 1 次減衰定数より大きくなる傾向がみられ, 振動数比例型の傾向が確 認されているといえる。

一方, 空間構造物の動的応答評価でも，数種類の地震波について 弾性地震応答解析, 弾塑性地震応答解析などを行い同様に建物の安 全性が検討されている。そその場合, 減衰は振動数比例型で1次のも一 ドに対して減衰定数を $2 \%$ とすることが多い2)。しかしこれは前述の. 鉄骨系重層建築物の設計時に使用されている慣用值を援用している に過ぎなく, 空間構造物の地震応答解析で減衰定数を振動数比例型 とすることは, 減衰を過大評価する恐れがあると指摘されている3)。 そこで空間構造物においてもより信頼性の高い耐震設計を実現する ためには，固有振動数や減衰定数などの振動性状をまず実験的に明
らかにしていくことは重要と言える。

空間構造物の振動実験は数少ないが, 早くは又木, 木下らは平面 直径134mの部分球殼を形成する二層ラチスドームの強制振動実験を 実施している。ドームはアングル材と鋼棒を用いて溶接接合で組み 立てられている。加力方法は水平方向は起振器, 上下方向はロープ 切断方式によっている。実験結果として減衰定数は次数に関係なく 一定 (2.7〜4\%) に近いことが示されている4)。その後, 斎藤, 黒 木らによってシステムトラスによるフレームのみの二層立体ラチス シェルの同様の強制振動実験が実施されており, 1 次减衰定数は 1.3 〜 1.5\%の結果が得られている5)。また常時微動と人力加振による自 由振動波形を用いた実験方法としては文献 6,7$)$ などがあり, 複層ラ チスドーム 1 次減衰定数は $2.1 \sim 6.5 \%$ 範囲にあり, 設計慣用值よ り大きい值を得ている。また，平面ラチス梁による剛節二層立体ラ チス平板や二層立体システムトラス平板の振動実験には文献8,9)な どが挙げられる。前者は支承部に粘性ダンパーが設置されており 1 次, 2 次減衰定数はそれぞれ約 $2,3 \%$ 得られている。これに対して 後者は一方向ローラー支持で約 $0.5 \%$ の減衰となっている。単層ラチ スドームについてはシステムトラス構造の振動実験が文献 10) で実 施されており，ロープ切断方式で減衰定数は平均 $0.2 \%$ となってお り, システムトラスの减衰は比較的小さいと言える。以上の結果は
本論文の一部は参考文献13)，14）で発表している。

* 大阪市立大学大学院工学研究科都市系専攻

助教授・博士 (工学)

** 大阪市立大学大学院工学研究科都市系専攻 教授・工博
Assoc. Prof., Dept. of Urban Engineering, Graduate School of Engineering, Osaka City University, Dr. Eng.

Prof., Dept. of Urban Engineering, Graduate School of Engineering, Osaka City University, Dr. Eng. 
いずれも実構造物の実測例である。

次に模型による振動実験として例えば，山田，田口らが打撃加振 法で P V C 材料の3角形網目の球形単層ラチスドームの固有振動数と 振動モードを調へており，打撃ハンマーの適切な選定により精度良 く実験結果が得られるとしている11)。大家，國枝らは平板と丸鋼で 組み立てた単層ラチスシリンダーの振動特性を振動台による水平加 振と打撃加振により調べており，得られた減衰定数が非常に小さい ことを示している12)。このように立体ラチスによる空間構造物の低 次の減衰定数は明らかにされつつあると言えるが，減衰定数と振動 数の関係は未だ十分に解明されていない。

そこで本研究は, 空間骨組構造物の固有振動数と減衰定数の関係 を明らかにするための実験データの蓄積として，まず仕上げ材など が取り付けられていないフレームのみの二層屋根型円筒ラチスシェ ルの自由振動性状を打撃加振法によって調べる。

\section{2. 試験体形状および部材特性}

試験体はFig. 1に示すようなねじ込み接合形式で組み立てられてい る。接合部は直径 $25.4 \mathrm{~mm}$ の鋼製球で, 部材は外径 $8 \mathrm{~mm}$ の鋼管であり, M6 のボルトで接続されている。試験体は $2 \times 6$ ユニットと $5 \times 5$ ユ ニットから成る2種類の二層屋根型円筒ラチスシェルであり,その全 体形状寸法をFig. 2 に示す。また，試験体に用いた部材の緒元を Table 1 に示す。試験体の重量は $2 \times 6$ ユニットが約 $9.5 \mathrm{kgf}, 5 \times 5$

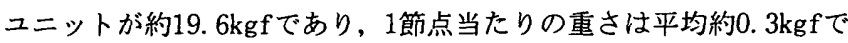
ある。

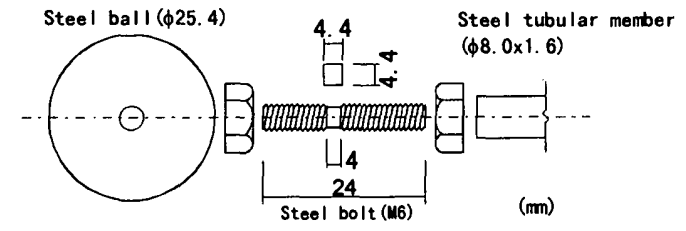

Fig. 1 Jointing System

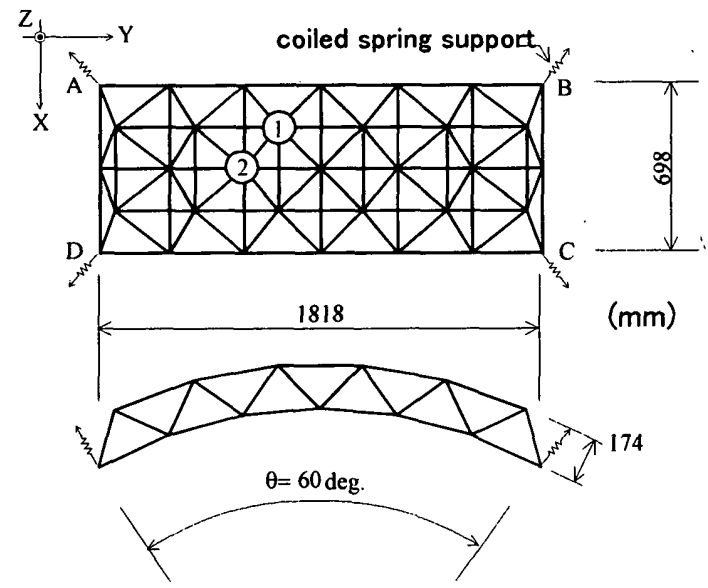

(a) $2 \times 6$ units
Table 1 Mechanical Properties of Members

\begin{tabular}{|c|c|c|}
\hline Diameter of ball joints & 2.54 & $(\mathrm{~cm})$ \\
\hline Rotational connecting rigidity $C_{j}$; & $3.48 \times 10^{3}$ & $(\mathrm{kgf} \cdot \mathrm{cm})$ \\
\hline $\begin{array}{l}\text { section area } A ; \\
\text { moment inertia } I\end{array}$ & $\begin{array}{l}0.8 \times{ }^{t} 0.16 \\
0.27 \\
0.0183\end{array}$ & $\begin{array}{l}(\mathrm{cm}) \\
\left(\mathrm{cm}^{2}\right) \\
\left(\mathrm{cm}^{4}\right)\end{array}$ \\
\hline $\begin{array}{l}\text { Weight of a ball joint ; } \\
\text { Weight of a tubular member } \\
\text { (Length }=29.5 \mathrm{~cm} \text { ) }\end{array}$ & $\begin{array}{l}0.049 \\
0.069\end{array}$ & $\begin{array}{l}\text { (kgf) } \\
(\mathrm{kgf})\end{array}$ \\
\hline Modulus of elasticity $E$ & $2.10 \times 10^{6}$ & $\left(\mathrm{kgf} / \mathrm{cm}^{2}\right)$ \\
\hline
\end{tabular}

\section{3. 振功実跧方法}

境界条件として，試験体のみの自由振動を実現するために支持剛 性を小さくかつ明確な值に設定でき，减衰をできるだけ小さくする ために，試験体の 4 隅の節点 $\mathrm{ABCD}$ を瞢巻ばねで吊るす方法を採用す る。その結果, $2 \times 6$ ユニットの試験体で剛体移動の振動数は $\mathrm{x}$ 方向 $0.18 \mathrm{~Hz}, \mathrm{y}$ 方向 $0.71 \mathrm{~Hz}, \mathrm{z}$ 方向 $1.71 \mathrm{~Hz}$ となる。 $5 \times 5$ ユニットの場 合, $\mathrm{x}$ 方向 $0.34 \mathrm{~Hz}, \mathrm{y}$ 方向 $0.40 \mathrm{~Hz}, \mathrm{z}$ 方向 $1.08 \mathrm{~Hz}$ である。振動実験 には打撃加振法を用いる。打撃はFig. 2に番号で示す各節点にラチス シェル面に対して法線方向に行う。振動応答は各節点毎に母線方向, アーチ接線方向，法線方向の加速度を同時に測定する。実験は同一 試験体で異なる日時に合計2回実施する。実験システムはエーアンド デイ製の加振 1 チャンネル, 応答 3 チャンネルのインパルスハンマ セット(AD-1228)であり,インパクトチップには硬質プラスチックを 用いる。加速度センサは電圧出力型で重量 $7.5 \mathrm{~g}$ で応答周波数は 2 $10000 \mathrm{~Hz}$ で, 1節点当たりの試験体重量に対する比率は約 $2 \%$ となって いる。またセンサの取り付けには両面テープを用いている。インパ ルスハンマによる入力信号と加速度センサによる応答出力信号とよ り，FFTアナライザ(AD3921)を用いて周波数応答関数を測定する。本 実験でのFFTの周波数レンジは最大 $500 \mathrm{~Hz}$ とし, 分解能は $0.625 \mathrm{~Hz}$ で ある。各実験では5回以上の打撃加振を実施し, 測定した際にコヒー

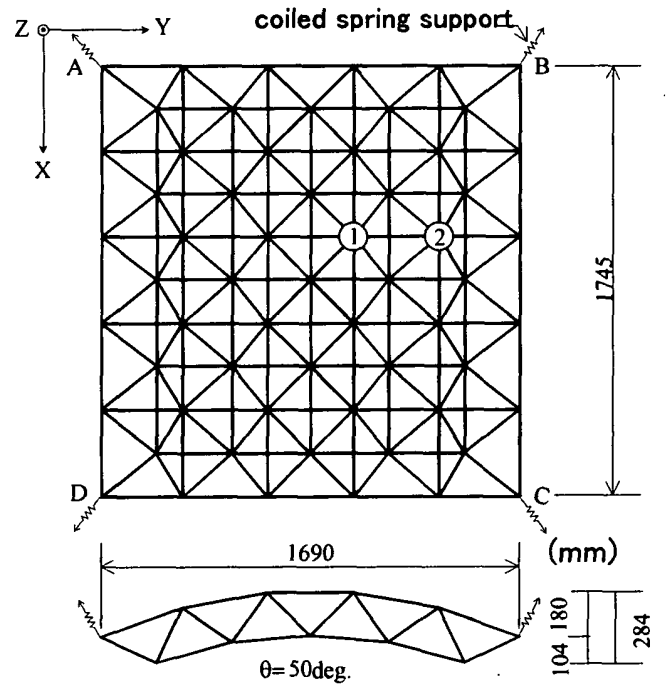

(b) $5 \times 5$ units

Fig. 2 Double-Layer Cylindrical Latticed Model 
レンスの良好なものを5個選び,その平均としで周波数応答関数を算 出する。また標本時間 $(1.6$ 秒) で $95 \%$ 減衰する指数関数型の空関数 を用いる。測定した周波数応答関数を用いて，各モードピークにつ いて関数を当てはめ, “固有振動数と減衰定数を算出する。カーブ フィットには市販のモード解析システム(日本サーク社StarSystem) を用いる。そこでは部分分数型の多項式を最小 2 乗残差法によって求 めている。

\section{4. 実験結果}

実験で得られた各試験体の節点番号1の加振入力による周波数応答 曲線の一部をFig. 3 とFig. 4に示す。図中の周波数応答曲線の明瞭な 峰の内, $\nabla$ 印付近の周波数の振動モードを, $2 \times 6$ ユニットの場合に は 2 個， $5 \times 5$ ユニットの場合は 5 個，それぞれFig. 5 とFig. 6 に示 す。周波数応答曲線について, Fig. 3 に示す $2 \times 6$ ユニットの場合, 図中に示す 3 点 $\mathrm{a}, \mathrm{b}, \mathrm{c}$ の峰が大きく現れ，しかも互いに一致している 振動数は約 $122 \mathrm{~Hz}, 144 \mathrm{~Hz}, 270 \mathrm{~Hz}, 435 \mathrm{~Hz}$ 前後である。振動数が $120 \mathrm{~Hz}$ から $450 \mathrm{~Hz}$ 全域に渡ってもある程度明瞭な峰が現れていると言える。 特に振動数 $200 \mathrm{~Hz}$ から $400 \mathrm{~Hz}$ 間は各固有振動数は接近している。

次にFig. 4 の $5 \times 5$ ユニットの場合, 振動数が約 $169 \mathrm{~Hz}$ と $487 \mathrm{~Hz}$ 付 近に明瞭な峰が複数見られたが, $200 \mathrm{~Hz} か ら 400 \mathrm{~Hz}$ までの振動数領域 では $2 \times 6$ ユニットの場合ほど大きく一致するような明瞭な峰は現れ ていない。この領域では同様に固有振動数が非常に接近しており, モードが連成していると思われる峰が多数現れている。

次にFig. 5 とFig. 6 の振動モードについて概説する。図中の矢印は 試験体中央部の変形の様子を示している。Fig. 5の(a)はア一チ方向 の曲げ変形モードで, (b) は四角錐ユニットの下弦材が伸縮するよう な変形で全体的には曲げ変形モードと類似している。Fig. 6の(a)は 母線方向（ $\mathrm{x}$ 方向）の曲げ変形が大きいモードであり，(b)はアーチ 方向（ $\mathrm{y}$ 方向）の曲げ変形と母線方向 ( $\mathrm{x}$ 方向)の比較的小さい曲げ 変形モードが混ざったものである。(c)は曲率の符号が互いに異なる 2 方向の曲げ変形モードとなっている。また $(\mathrm{d})$ は支持部周辺が大きく 上下に振動し, 全体的には曲率の符号が等しい2方向の曲げ変形モー ドである。(e)は中央部付近と境界辺付近が反対方向に上下に振動す る変形モードである。

最後にモード解析によって得られた固有振動数と減衰定数の関係 をFig. 7 とFig. 8にそれぞれ示す。図中の黒丸と白丸は実験日が異な るデータをプロットしたものである。 $2 \times 6$ ユニット試験体の場合は 減衰定数は最大で $0.61 \%$ であり, 周波数応答曲線で峰の高い $122 \mathrm{~Hz}$ で $0.55 \%$ となっている。その他の高い峰の減衰定数はその值よりも 小さくなっている。全体平均は $0.26 \%$ あるあ。また $5 \times 5$ ユニット 試験体の場合には, 减衰定数は最大で $0.70 \%$ であり, 周波数応答曲 線で峰の高い $169 \mathrm{~Hz}$ で約 $0.30 \%$, 全体の平均では $0.23 \%$ となってい る。いずれの試験体でも，周波数応答関数で高い峰が現れた振動 モードの減衰定数は平均值より若干高い傾向にあるといえる。

次に減衰定数と振動数の関倸について，図中の一点鎖線は最小 2 乗法で回帰直線を求めたものである。その結果, 周波数が高いほど 減衰定数が小さい傾向となっている。また相関関係が強くないこと からも減衰定数は振動数に大きく依存しているとは言えない。

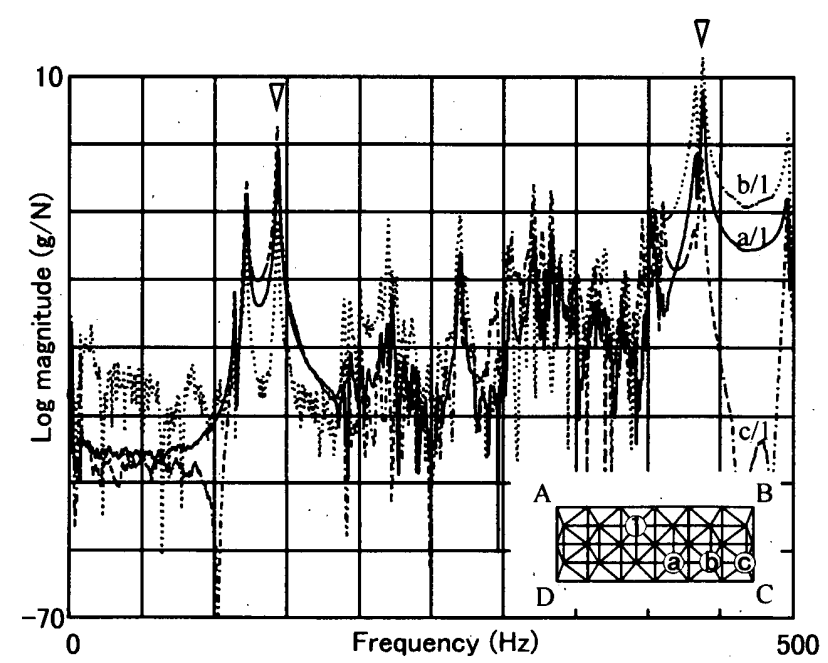

Fig. 3 Frequency Response Curves of $2 \times 6$ Units

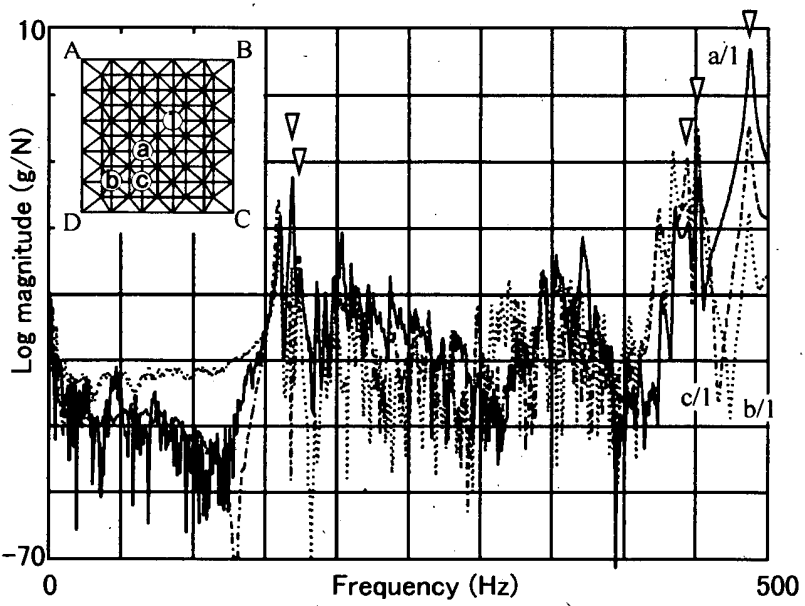

Fig. 4 Frequency Response Curves of $5 \times 5$ Units

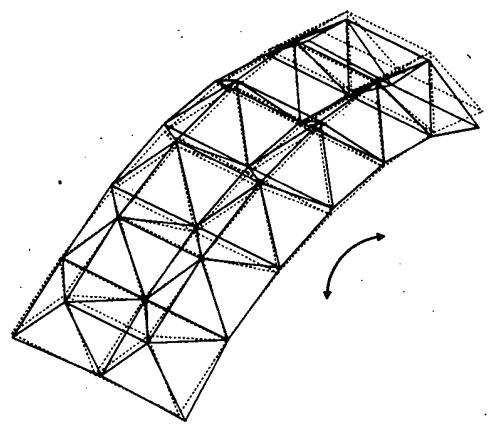

(a) $143.9 \mathrm{~Hz}$

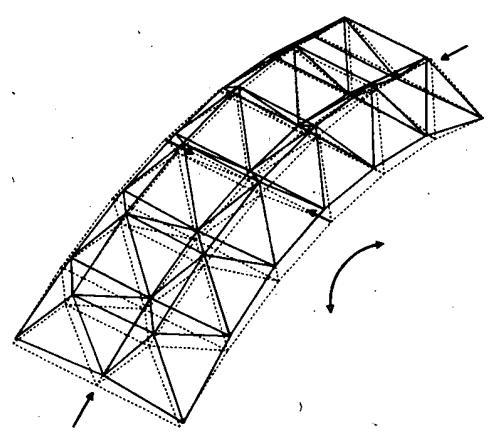

(b) $436.9 \mathrm{~Hz}$

Fig. 5 Free Vibration Modes of Impact No. 2 


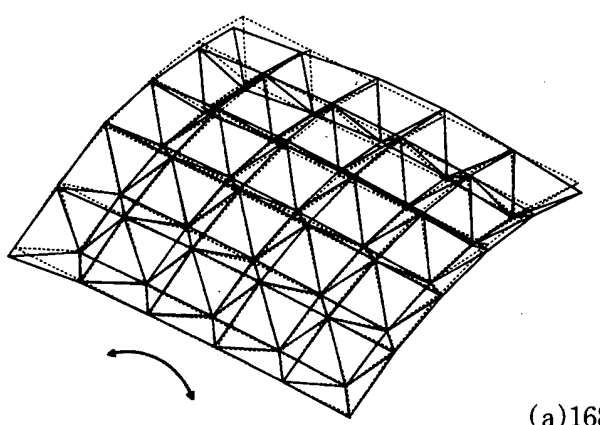

(a) $168.7 \mathrm{~Hz}$

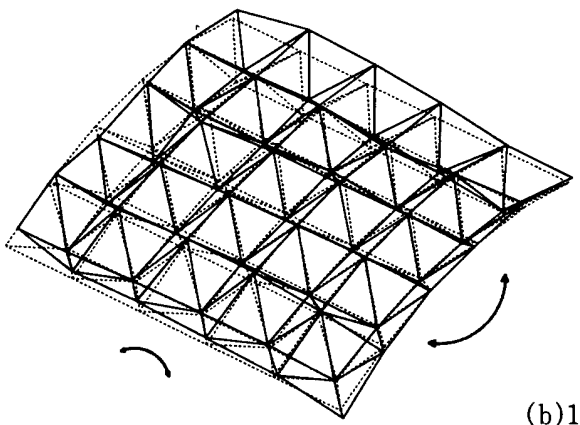

(b) $174.5 \mathrm{~Hz}$

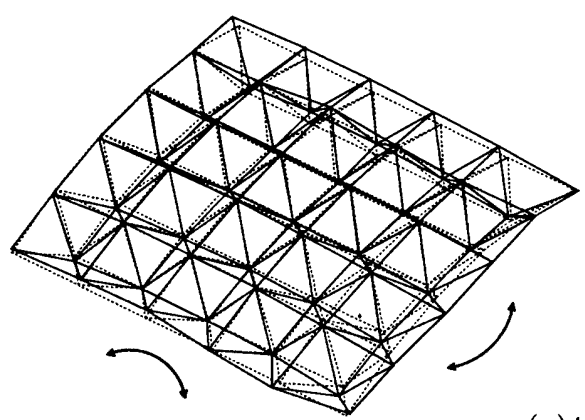

(c) $445.9 \mathrm{~Hz}$

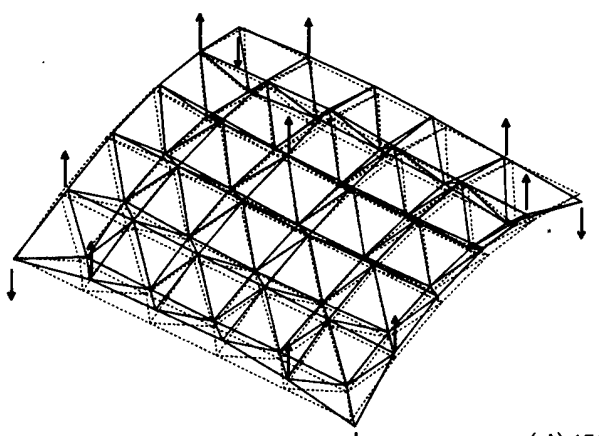

(d) $452.8 \mathrm{~Hz}$

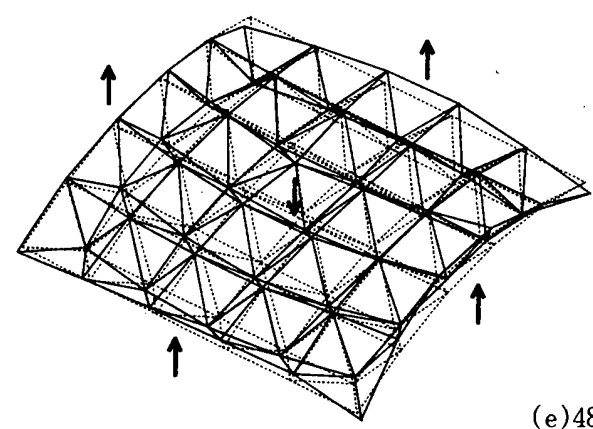

(e) $487.8 \mathrm{~Hz}$

Fig. 6 Free Vibration Modes of Impact No. 1

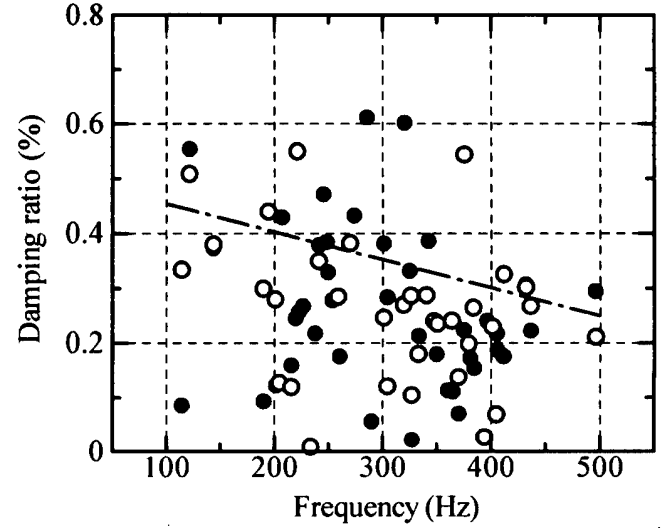

Fig. 7 Frequency-damping relation of $2 \times 6$ units

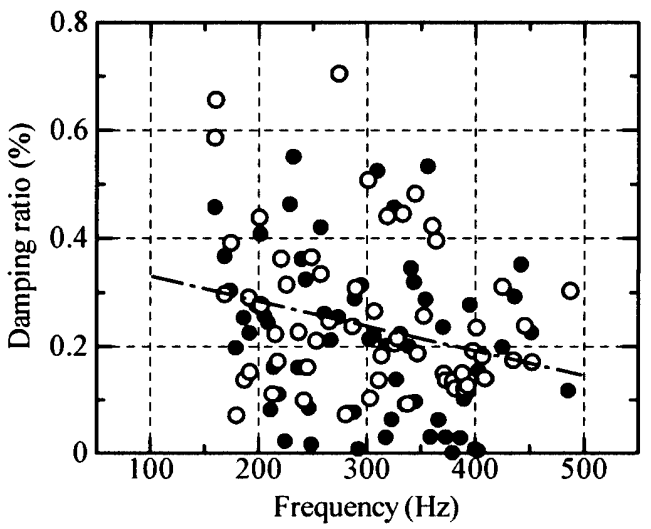

Fig. 8 Frequency-damping relation of $5 \times 5$ units

\section{5. 考察}

実験結果と比較検討するために非減衰自由振動解析を行う。試験 体の部材と接合部をFig. 9に示すようにモデル化する。ボルトとナッ トの質量は節点への集中質量とし，パイプ材の質量は整合質量とす る。また本試験体は㸚じ込み接合形式で組立てられているので, 部 材のねじり剛性率を 0.01 とした。解析では振動数 $500 \mathrm{~Hz}$ を超えるま での固有振動数と固有モード，刺激係数を算定する。ここでの刺激

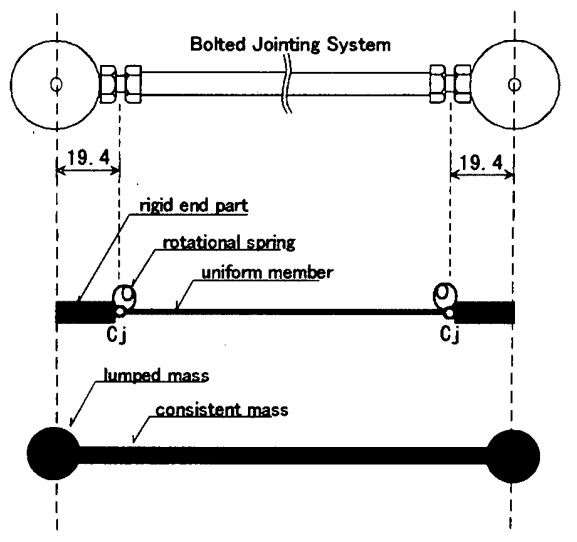

Fig. 9 Numerical Model for Member and Joint 
係数は剛性行列で正規化した固有モードより算出したものである。 各試験体の固有振動数と刺激係数の分布をFig. 10 に示す。また鉛 直方向の刺激係数の絶対值が大きい順から並べ替えたものの内上位 10 個をTable2 と Table3に示す。

Fig. 10 より高次の振動モードでも刺激係数の大きい場合があり, モードの次数と刺激係数に相関関係が見られないことが分かる。

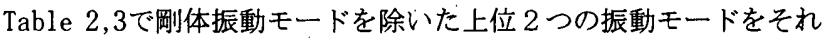
ぞれFig. 11，12に示す。これら鉛直方向の刺激係数の大きくなってい るモードの振動数は $2 \times 6$ ユニット試験体の場合 $146.5 \mathrm{~Hz}$ と $424.5 \mathrm{~Hz}$ であり，振動モードはFig. 11(a)でアーチ方向の曲げ変形モードと なっており，実験結果と振動数，モードともほぼ一致している。 Fig. 11(b)では同様の曲げ変形が卓越しているが,下面の網目が菱形 に変形するモードが混ざっている。実験では振動数が解析值より約 $3 \%$ 高いところで明瞭な峰が現れて, 類似の曲げ変形振動モードが見 られている。

$5 \times 5$ ユニット試験体では $173.7 \mathrm{~Hz}$ と $396.9 \mathrm{~Hz}$ であり, Fig. 12(a)は $\mathrm{x}$ 方向の曲げ変形モードが卓越しており, 実験で得られたモード (Fig. 6(b)) と振動数, モードともほぼ一致している。Fig. 12(b)はシ リンダー中央部と境界辺付近が互いに反対方向に上下に変形する振 動モードとなっている。実験ではこの振動数付近において周波数応 答関数に明瞭な峰が現れずモード同定には至らなかったが，類似の 振動モードは $487.8 \mathrm{~Hz}$ で現れている。

最後に, 実験で得られた周波数応答関数に明瞭な峰を示す振動 モードはラチスシェルの1方向あるいは2方向の曲げ変形モードであ

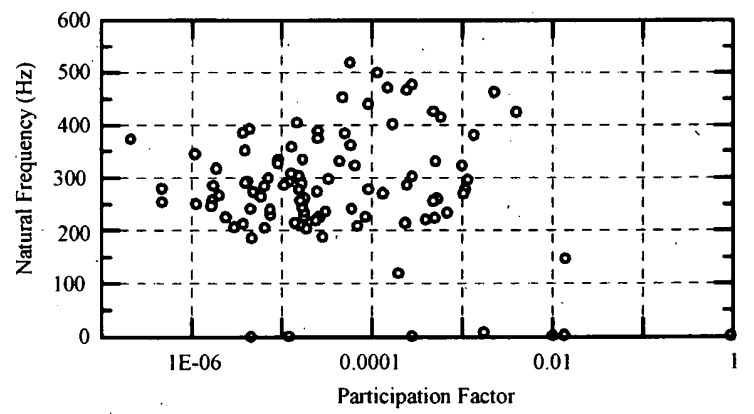

(a) $2 \times 6$ Units

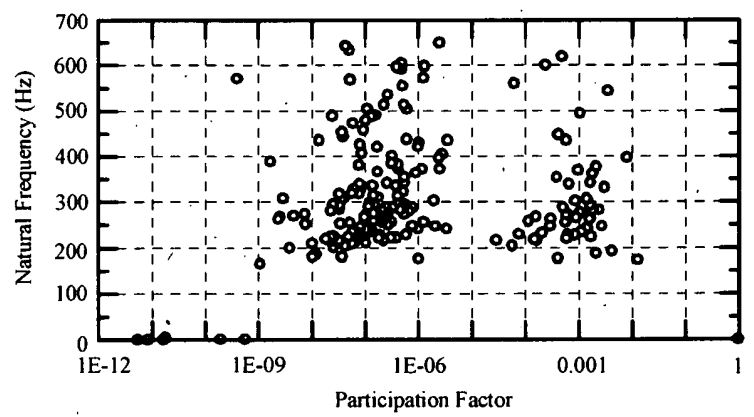

(b) $5 \times 5$ Units

Fig. 10 Natural Frequency and Participation Factor of Vibration Mode in the Vertical Direction
Table 2 Numerical Results of $2 \times 6$ Units

\begin{tabular}{|c|c|c|c|c|}
\hline \multirow{2}{*}{$\begin{array}{c}\text { Number of } \\
\text { Mode }\end{array}$} & \multicolumn{3}{|c|}{ Participation Factor } & \multirow{2}{*}{$\begin{array}{c}\text { Natural } \\
\text { Frequency } \\
(\mathrm{Hz})\end{array}$} \\
\hline & $\mathrm{x}$ & $\mathrm{y}$ & $\mathrm{z}$ & \\
\hline 4 & $8.442 \mathrm{E}-05$ & $9.214 \mathrm{E}-04$ & $-9.547 \mathrm{E}-01$ & $1.565 \mathrm{E}+00$ \\
\hline 9 & $-3.035 \mathrm{E}-06$ & $-1.320 \mathrm{E}-05$ & $-1.390 \mathrm{E}-02$ & $1.465 \mathrm{E}+02$ \\
\hline 6 & $2.668 \mathrm{E}-04$ & $-5.440 \mathrm{E}-02$ & $-1.360 \mathrm{E}-02$ & $2.519 \mathrm{E}+00$ \\
\hline 5 & $-8.240 \mathrm{E}-03$ & $-1.812 \mathrm{E}-03$ & $-1.016 \mathrm{E}-02$ & $2.168 \mathrm{E}+00$ \\
\hline 91 & $2.425 \mathrm{E}-07$ & $3.588 \mathrm{E}-06$ & $-3.969 \mathrm{E}-03$ & $4.245 \mathrm{E}+02$ \\
\hline 95 & $-2.785 \mathrm{E}-06$ & $3.592 \mathrm{E}-05$ & $-2.290 \mathrm{E}-03$ & $4.628 \mathrm{E}+02$ \\
\hline 7 & $-3.906 \mathrm{E}-06$ & $-3.045 \mathrm{E}-04$ & $1.758 \mathrm{E}-03$ & $8.371 E+00$ \\
\hline 83 & $-1.551 \mathrm{E}-06$ & $1.550 \mathrm{E}-05$ & $-1.355 \mathrm{E}-03$ & $3.808 \mathrm{E}+02$ \\
\hline 63 & $1.308 \mathrm{E}-07$ & $3.128 \mathrm{E}-07$ & $-1.165 \mathrm{E}-03$ & $2.960 \mathrm{E}+02$ \\
\hline 53 & $7.310 \mathrm{E}-09$ & $-3.557 \mathrm{E}-05$ & $-1.083 \mathrm{E}-03$ & $2.783 \mathrm{E}+02$ \\
\hline
\end{tabular}

Table 3 Numerical Results of $5 \times 5$ Units

\begin{tabular}{c|c|c|c|c}
\hline \multirow{2}{*}{$\begin{array}{c}\text { Number of } \\
\text { Mode }\end{array}$} & \multicolumn{3}{|c|}{ Participation Factor } & $\begin{array}{c}\text { Natural } \\
\text { Frequency } \\
(H z)\end{array}$ \\
\cline { 2 - 4 } & $\mathrm{x}$ & $\mathrm{y}$ & $\mathrm{Z}$ & $1.080 \mathrm{E}+00$ \\
4 & $-2.684 \mathrm{E}-11$ & $1.391 \mathrm{E}-11$. & $9.590 \mathrm{E}-01$ & 1.00 \\
9 & $2.037 \mathrm{E}-08$ & $-1.549 \mathrm{E}-10$ & $-1.280 \mathrm{E}-02$ & $1.737 \mathrm{E}+02$ \\
158 & $1.224 \mathrm{E}-08$ & $1.578 \mathrm{E}-09$ & $-7.866 \mathrm{E}-03$ & $3.969 \mathrm{E}+02$ \\
16 & $-2.786 \mathrm{E}-09$ & $2.032 \mathrm{E}-10$ & $-4.094 \mathrm{E}-03$ & $1.935 \mathrm{E}+02$ \\
185 & $2.858 \mathrm{E}-08$ & $-9.159 \mathrm{E}-09$ & $-3.442 \mathrm{E}-03$ & $5.438 \mathrm{E}+02$ \\
133 & $-8.130 \mathrm{E}-09$ & $5.179 \mathrm{E}-10$ & $3.010 \mathrm{E}-03$ & $3.314 \mathrm{E}+02$ \\
63 & $-2.241 \mathrm{E}-09$ & $4.823 \mathrm{E}-06$ & $2.687 \mathrm{E}-03$ & $2.473 \mathrm{E}+02$ \\
101 & $1.365 \mathrm{E}-09$ & $-1.901 \mathrm{E}-08$ & $-2.356 \mathrm{E}-03$ & $2.827 \mathrm{E}+02$ \\
151 & $2.512 \mathrm{E}-08$ & $-8.555 \mathrm{E}-09$ & $2.132 \mathrm{E}-03$ & $3.771 \mathrm{E}+02$ \\
15 & $-1.279 \mathrm{E}-09$ & $1.094 \mathrm{E}-10$ & $2.101 \mathrm{E}-03$ & $1.878 \mathrm{E}+02$ \\
\hline
\end{tabular}

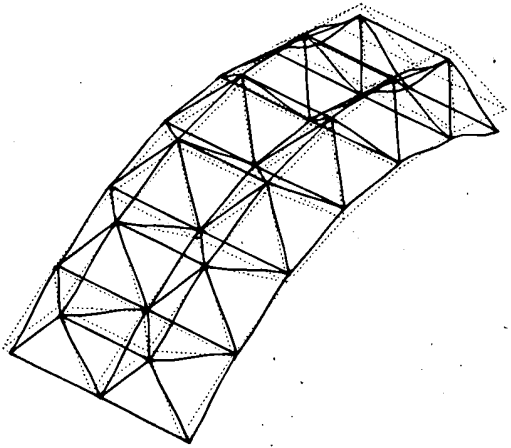

(a) $146.5 \mathrm{~Hz}$

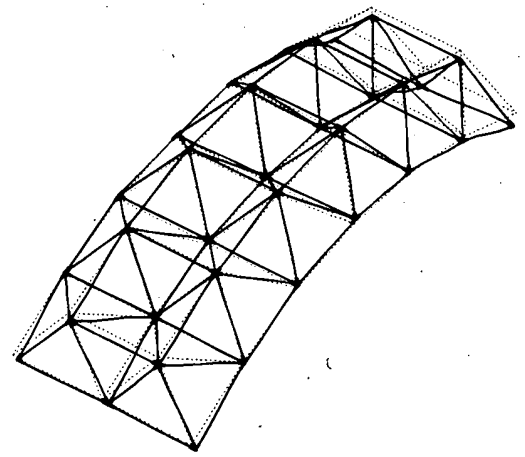

(b) $424.5 \mathrm{~Hz}$

Fig. 11 Free Vibration Mode obtained by Numerical Analysis 


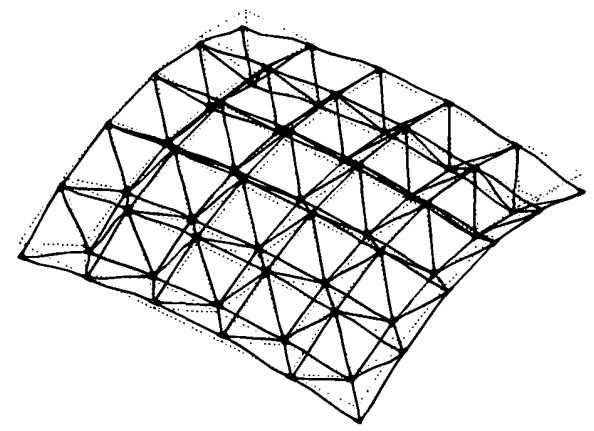

(a) $173.7 \mathrm{~Hz}$

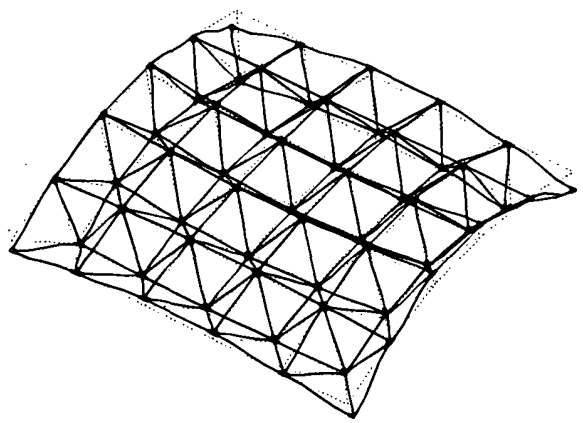

(b) $396.9 \mathrm{~Hz}$

Fig. 12 Free Vibration Mode obtained by Numerical Analysis

る。振動数を見ると，1 方向の曲げ変形振動モードは一番小さく，次 いで曲率の互いに異なる2方向曲げ変形振動モードの順に大きくなっ ている。

\section{6. 結ひ}

構造体のみの二層屋根型円筒ラチスシェルの自由振動実験を打撃 加振法により実施し, 固有振動数と減衰定数を調べた。その結果, 本 研究の範囲では減衰定数は振動数に反比例する傾向にあり, 減衰定 数はほほ $1 \%$ \%小さいことが分かった。

また，鈶直方向に刺激係数の大きい曲げ変形振動モードは振動実 験において大きな応答を示した。なお，一方向的な $2 \times 6$ ユニット試 験体では, 高次の振動数領域までモードの同定は行えたが, 面的広 がりを有する $5 \times 5$ ユニット試験体の場合には, 高次振動数領域で モードが非常に接近し，モード同定が明瞭に行えない領域があった。

今後は，屋根仕上げ材などを取り付けた場合の振動実験を実施す る。そのことによって実構造物の固有振動数と減衰定数の関係の解 明，および減衰定数の設定法に有用な資料を提供できる。

\section{期辞}

本研究の一部は平成 10 年度東京工業大学特定共同研究（代表 新宮清志）の援助によった。実験は岩木宣憲君に多大な協力を得た ことに感謝します。

\section{考文献}

1）建築物の堿哀, 日本建築学会, 丸善, 2000 年 10 月

2）空間棬造の耐震設計と設計例, 日本建築学会, 丸善, 2001 年 1 月

3）立道郁生 : 既往の振動計測に基づく空間構造の诚言性能に関する一考察, 平成 12 年度京都大学防災研究所共同研究集会, 大空間樓造に想定し得る 被災の原因と対策, pp. $67 \sim 77$, 平成 12 年 11 月

4) 又木義浩, 木下勝弘, 相沢党, 吉田啓喜: 球殻ドーム（名古屋国際展示 場）の強制振動実験, 日本建築学会大会学術講演梗概集（北陸）, pp. 603 $\sim 604$, 昭和 49 年 10 月

5）紊藤公男, 黒木二三夫, 岡田章 : 立体トラスシェルの振動実験および振 動解析（ポートピア’ 81 国際広場大屋根構造の研究報告一2), 日本建 築学会大会学術講演梗概集 (九州), pp. 1191-1192, 昭和 56 年 9 月

6) 高木政美, 細沢治, 山田正明, 島村高平, 久野雅祥 : ドーム屋根の减衰 定数, 日本建築学会大会学術講演梗概集 (九州), pp. $997 \sim 998,1998$ 年 9 月

7) 安間由倫, 立道郁生, 藤原智, 藤同敏雄, 䳋登志男, 八木敏行, 田中宏 幸 : 低ライズ複層トラスドームの振動実験; 日本建築学会大会学術講演 梗概集（中国），pp. $911 \sim 912 ， 1999$ 年 9 月

8）奥野智久, 小野徹郎, 岡田章, 木村衛, 相沢党, 犬飼伴幸, 最上公彦, 畑中公樹：大スパントラス屋根の実举動に関する研究（その 2$)$ 静的載 荷実験および自由振動実験, 日本建築学会大会学術講演梗概集（中国）, pp. $1329 \sim 1330,1990$ 年 10 月

9）関本厷幸, 藤田正則, 富本淳, 岩田衛: 制振ダンパーを有する平面シス テムトラスの研究（その 2 制振ダシパーの適用例）, 日本建築学会大会学 術講演梗概集 (関東), pp. $841 \sim 842,2001$ 年 9 月

10）田波徹行, 黒木二三夫, 奥原剛彦, 大矢俊治, 半谷裕彦, 戸田郁也：単 層スペースフレーム（EＸＰＯ'85 南ゲートドーム）の自由振動実験， 日本建築学会大会学術講演梗概集 (北海道), pp. $279 \sim 280,1986$ 年 8 月

11）山田聖志, 田口孝, 河相成樹, 山田大彦, 楠達明 : インパルスハンマ法 によるラチスシェルの振動実験（その 2 球形ラチスシェルの自由振動性 状), 日本建築学会大会学術講演梗概集（東海）, pp. $1899 \sim 1900 ， 1994$ 年 9 月

12）大家貴徳，國枝治郎：屋根型円简形単層ラチスシェルの地震応答測定実 験, 日本建築学会大会学術講演梗概集 (九州), pp. 909 910, 1998 年 9 月

13）谷口与史也, 坂尋二, 岩木宣憲 : 二層屋根型円筒ラチスシェルの固有振 動数と減衰定数, 日本建築学会近畿支部研究報告集第 39 号構造系, pp. $141 \sim 144$, 平成 11 年 6 月

14）谷口与史也, 坂尋二 : 二層屋根型円筒ラチスシェルの自由振動性状, 平 成 11 年度京都大学防災研究所共同研究集会, シェル・空間構造の耐展, 耐風, 耐雪, 耐火を考えた性能設計と解析, pp. $155 \sim 162$, 平成 11 年 11 月

（2002年11月 5 日原稿受理， 2003 年 5 月 28 日採用決定） 